\title{
REPRODUCTIVE TECHNOLOGIES FOR CONSERVATION OF GENETIC RESOURCES OF ENDANGERED EQUIDAE: A REVIEW
}

\author{
George Yu. Maksudov*, Ksenia I. Egorova
}

\author{
V.A. Afanasjev Federal State Funded Scientific Institute of Fur Animal and Rabbit Breeding, Russia \\ *e-mail:sapienceman@mail.ru
}

Received: 20.04.2019. Revised: 10.05.2019. Accepted: 11.05.2019.

\begin{abstract}
This review presents data on the use of assisted reproductive techniques to obtain offspring and preserve the genetic resources of wild Equidae including the Przewalski's horse Equus ferus przewalskii. Some results and applied techniques in obtaining and cryopreservation of sperm, embryo transfer, including interspecies, as well as the possibility of studying and regulation of the oestrous cycle in rare and endangered equids are described. The main method of collecting sperm from wild equid species was electroejaculation of immobilised males. Some parameters of sperm are given: $\mathrm{pH}$, volume, osmotic characteristics of the semen. The influence of various cryoprotectors and diluents on the survival of spermatozoa during cryopreservation is considered in a few papers. Cryopreservation of sperm of Przewalski's horses and Grevy's zebras E. grevyi were conducted. After artificial insemination of frozen-thawed spermatozoa of a Grevy's zebra, one mare of the domestic horse E.f. caballus became pregnant. For transplantation of blastocysts from Przewalski's horses and Grant's zebras E. quagga boehmi to domestic donkeys E. africanus asinus and ponies E. f. caballus, both surgical and non-surgical methods were used. Four foals were born as a result the surgical transplantation of nine embryos from Przewalski's horses to ponies. Twelve zebra's embryos were transplanted into five ponies and seven donkeys. These ponies gave birth to two foals, no embryos in the donkeys had fully developed till the birth. The only experiment of non-surgical transplantation of a zebra embryo was unsuccessful. Results of a study of the oestrous cycle of the Przewalski's horse and Grevy's zebra by methods of ultrasound examinations and analysis of samples of urine and faeces were showed. For some species of other wild equids, the cycle was determined by behavioural reactions. The possibility of influencing the cycles of mares of Przewalski's horses by prostaglandins given orally or with injections was discussed. Results of assisted reproductive techniques applied to domestic horses are recommended as a possible model for the creation of the Genome Resource Bank for wild equids. Further optimisation of current methods used in the reproduction of domestic horses, such as intracytoplasmic sperm injection, cloning, make their use promising for the conservation of rare species of equids.
\end{abstract}

Key words: assisted reproduction techniques, cryopreservation, embryo transfer, Equus ferus przewalskii, genome resource banking, wild equids

\section{Introduction}

When in situ conservation of a species becomes impossible, the last resort is ex situ conservation, which refers to the establishment of a viable population (in captivity for eventual reintroduction) and the start up of a Genome Resource Bank (and Assisted Reproductive Technologies (ART)) (Maksudov et al., 2014).

ART are the innovative trend of environmental biotechnology. These technologies involve the use of experimental embryology and cryobiology methods for genetic conservation of threatened and endangered species more over for obtaining an offspring from them, if natural reproduction is impossible and the preservation of the genetic diversity is difficult. ART is extremely important for the threatened equids due to: 1) little abundance of species and their increasing extinction rates; 2) origin of current population from a small number of founders (e.g., Przewalski's horse Equus ferus przewalskii
Poliakov, 1881): 3) danger of their natural biotopes complete degradation and impossibility of preserving these species in the environment; 4) limited possibilities of zoological parks and breeding centers in their preservation; 5) other internal reasons. At present, many species of wild equids are endangered. Recently the only measure taken to prevent extinction of wild equids has been breeding in captivity (Kaczensky et al., 2011). This is a short review on the assisted reproductive technologies (ART) of wild equids including the Przewalski's horse.

The EAZA (European Association of Zoos and Aquaria) Biobank mission was founded in 2016. The Biobank focuses on collecting biological material from zoos, which are members of this organisation.

This succinct overview is devoted to the Przewalski's horse, mainly. It is the first review of this kind in the generally available literature. Objective of the work: collecting and systematisation of the available data for planning research on the theme in question. 


\section{Material and Methods}

Modern reproductive biotechnologies or ART including artificial insemination, embryo transfer, in vitro fertilisation, gamete/embryo micromanipulation, semen sexing, genome resource banking, and somatic cell nuclear transfer (cloning) could be used in conservation programs for endangered species of mammals. ART allow more offspring to be obtained from selected parents to ensure genetic diversity and may reduce the interval between generations. It has been developed to obtain pregnancies from subfertile mares and stallions and to save gametes after death (Maksudov et al., 2008). Modern reproductive biotechnologies for the domestic horse $E$. $f$. caballus Linnaeus, 1758 have progressed from embryo transfer to oocyte maturation, oocyte transfer, intracytoplasmic sperm injection, embryo biopsy, embryo vitrification, and cloning (Asa, 2002; Allen et al., 2011). In practice, current ART are inefficient for many endangered animals because of insufficient knowledge on basic reproduction like oestrous cycle, seasonality, structural anatomy, gamete physiology of non-domestic species.

In such species as the Przewalski's horse, the technology of artificial insemination (AI) is especially important, since the current population in the world is based on 14 founder animals. With extinction in the wild, genetic management is critical for overall conservation of the species ex situ and in situ. AI and related technologies will facilitate breeding with founder genetics without transportation of animals, since moving and maintaining animals can be life threatening, expensive, and logistically impractical, considering that many zoological institutions are not equipped to house and manage Przewalski's stallions and other wild equid males. The major difficulty in the development of ART to wild equids is the limited knowledge base of reproductive physiology in those species.

\section{Results and Discussion}

\section{Sperm collection and cryoconservation}

Since the studies involve a limited number of animals, knowledge of semen characteristics in wild equids is still rudimentary. Research on domestic species under controlled conditions provides an excellent opportunity to develop effective semen handling techniques for application to endangered wild species.

Collecting semen from a wild stallion involves electroejaculation under general anaesthesia. (Stover et al., 1981; Collins et al., 2006; Durrant, 1990). The efficiency of obtaining spermic ejaculates was $100 \%$, but the ejaculate quality was highly variable. Although sperm from domestic stallions can be routinely collected using an artificial vagina, this method is not applicable for wild equids. Recently, electroejaculation has yielded encouraging results in the endangered Przewalski's horse (Collins et al., 2006). The osmolality of the Przewalski's horse semen was similar to that of the domestic horse, average $\mathrm{pH}$ of semen samples in this study was lower than those reported for the domestic stallion. Average $\mathrm{pH}$ of Przewalski's stallion sperm samples was lower than those reported for the domestic stallions. The amount of fluid measured volumetrically and $\mathrm{pH}$ tested using a colorimetric strip (Collins et al., 2006).

Semen for the ultimate success of AI in wild equids will require continued research on the «stallion effect», extenders and cryoprotectants, optimal volume and number of spermatozoa, temperatures during handling, processing an transport, and insemination techniques.

Cryopreservation of germplasm of threatened or endangered species has been proposed as an approach to slow or halt the rate of species decline. One mission under this approach is for organised repositories such as the Genome/Genetic Resource Banks (GRB) to cryopreserve spermatozoa from every genetically valuable male, thus may provide the insurance against extinction of a particular species. Also, AI with frozen semen would allow infusion of genetic material from free-ranging and captive animals across zoos and, perhaps, back into the wild to maintain genetic diversity.

Two studies were conducted to understand sperm cryosensitivity in the Przewalski's horse (Pukazhenthi et al., 2014). The first assessed the toxicity of permeating cryoprotectants (glycerol, methylformamide $[\mathrm{MF}]$ and dimethylformamide [DMF]) to Przewalski's horse spermatozoa during liquid storage at $4^{\circ} \mathrm{C}$. The second examined the comparative influence of three diluents (with or without formamides) on cryosurvival of sperm from the Przewalski's horses and domestic horses. There was no effect of cryoprotectants on sperm acrosomal integrity. In the cryosurvival study, average sperm motility and proportion of cells with intact acrosomes in fresh ejaculates were similar $(P>0.05)$ between the Przewalski's and domestic horse donors.

Semen of Grevy's zebra Equus grevyi Oustalet, 1882 was frozen in two different extenders in 0.5 $\mathrm{ml}$ straws. The post-thaw motility of cryopreserved spermatozoa ranged from $30 \%$ to $70 \%$. A domestic horse mare became pregnant on the first cycle af- 
ter insemination with frozen-thawed spermatozoa from this species (Crump \& Crump, 1994).

\section{Artificial insemination}

The technology has only recently started to apply to wild equids, because of the development of safe and effective practices of manual restraint for handling stallions and mares on a routine basis. Sex-sorted spermatozoa had yet to be applied to wild equids, the use of sex-sorted spermatozoa has great potential as a tool for breeding management and conservation of endangered wildlife, especially since re-population may be accelerated by producing predominantly female.

\section{Embryo collection and freezing, embryo transfer}

A remarkable characteristic of equids is that they are able to carry to term true xenogeneic extraspecies pregnancies created by embryo transfer (Allen et al., 2011), as a recipient for exotic equine embryos such as those of the Przewalski's horse and Grant's zebra Equus quagga boehmi Matschie, 1892 (Summers et al., 1987).

Blastocysts non-surgically collected from two Przewalski's horse and two Grant's zebra mares and transferred extra-specifically to the domestic horse and donkey E. africanus asinus Linnaeus, 1758 recipients (Summers et al., 1987). Then nine Przewalski's horse embryos were transferred surgically, and two non-surgically, to domestic Welsh-type pony mares. After surgical transfer, seven $(77.8 \%)$ pregnancies occurred and four foals were born. Twelve Grant's zebra embryos were transferred surgically to five pony and seven domestic donkey recipients respectively and one non-surgically to a donkey. Three $(60 \%)$ zebra-in-horse pregnancies were established and two went to term. Only two $(28.6 \%)$ zebra-in-donkey pregnancies were established but neither went to term, although one zebra foal was aborted alive at day 292 but failed to survive. No pregnancies resulted from the non-surgical transfers. The authors showed that measurement of chorionic gonadotrophin concentrations and parentalspecific lymphocytotoxic antibodies in the blood serum of the recipient animals indicated the obvious maternal immunological response to the extraspecific embryo. It could not be correlated with success or failure of pregnancy. The results indicate that extra-specific embryo transfer may be a useful aid to breeding exotic equids in captivity.

Sedated Przewalski's horses and Grant's zebra mares have been subjected to embryo recovery with good results $(61 \%$ and $56 \%$ recovery, respectively). Pregnancy rates for Przewalski's horse-to-domestic horse and Grant's zebra-to-domestic horse extraspecific pregnancies were 64\% and $60 \%$, respectively, with three live Przewalski's foals and one live zebra foal being born (27\% and $20 \%$ from embryos transferred) (Summers et al., 1987; Allen et al., 2011). The recovery of extinct equine species, making use of genetically close animals, is also underway.

It was found out that mares of domestic horsed and donkeys have been shown to be capable of carrying to term a range of true, xenogeneic extraspecies pregnancies created by embryo transfer Przewalski's horse (E. prezwalskii; $2 \mathrm{n}=66)$-in-horse, $(E$. caballus; $2 \mathrm{n}=64)$, and Grant's zebra (E. quagga boehmi; $2 \mathrm{n}=44$ )-in-horse pregnancies (Allen et al., 2011).

\section{Oestrous cycles studies and manipulation}

Characteristics of the oestrous cycle in Przewalski's horse and Grevy's zebra have been determined by monitoring hormone metabolites in urine and faeces (Summers et al., 1987). Reproductive characteristics in other wild equids, such as plains zebras E. quagga Boddaert 1785, Persian onagers E. hemionus onager Boddaert 1785, and kulan E. $h$. kulan Groves \& Mazak, 1967 have been determined by observing behaviour (Bahloul et al., 2001).

Although reproductive ultrasonography is used routinely in domestic equids, it has had limited use in wild equids. In an early study (Durrant \& Hoge, 1988) transrectal ultrasonography was used to monitor follicular development in anesthetised Przewalski's mares a few times throughout the breeding season. Durrant \& Hoge (1988) reported that in studied Przewalski's mares the cycle length and variability, ovarian response to prostaglandins (PG) and the rate of follicle growth was similar to those in domestic horse.

To date, there has been limited research on manipulation of the oestrous cycle in endangered equids. Collins et al. (2014) assessed the efficacy of using combinations of oral altrenogest and PGF2 $\alpha$, and injectable altrenogest and PGF2 $\alpha$ for manipulation of ovarian activity in Przewalski's mares. Reproductive cycles were monitored by assessing follicular changes with rectal ultrasound and changes in urinary steroid hormones. The results of Collins et al. (2014) indicate that manipulation of the oestrous cycle of Przewalski's mares can be achieved by administering oral or injectable form of altrenogest in conjunction with PGF $2 \alpha$. This could be essential for the development of timed artificial insemination as a genetic management tool for this critically endangered equids. 
Monfort et al. (1991) demonstrated that longitudinal reproductive events, including oestrous cyclicity and pregnancy, can be monitored precisely by evaluating urinary oestrogen conjugates in samples from Przewalski's mares maintained under semi-free-ranging conditions.

\section{Conclusions}

The progress in ART for non-domestic equid species will continue slowly due to limited resources, but also because the management and conservation of endangered species is biologically quite complex (Asa, 2002). The ultimate success of AI in wild equids will require continued research into the stallion effect, extenders and cryoprotectants, optimal volume and number of spermatozoa, temperatures during handling, processing and transport, and insemination techniques. In equids, research on domestic species under controlled conditions provides an excellent opportunity to develop effective semen handling techniques for application in wild and endangered species of the respective families.

The domestic horse is a good model for the establishment of a GRB in wild equids. Some techniques such as intracytoplasmic sperm injection (ICSI) and cloning are ready to be implemented, and further developments are needed to increase success rates in the future. (Asa, 2002). In addition, some of the available assisted reproduction technologies will need to be further optimised in the domestic horse before they can be applied to endangered wild equids.

\section{References}

Allen W.R., Kydd J.H., Short R.U., Antczak D.F. 2011. Interspecific and extraspecific equine pregnancies. In: A. McKinnon, E.L. Squires, W.E. Vaala, D.D. Varner (Eds.): Equine Reproducton. Chichester: Wiley-Blackwell. P. 2302-2323.

Asa C.S. 2002. Equid reproductive biology. In: P.D. Moehlman (Ed.): Equids: Zebras, Asses, and Horses. Status Survey and Conservation Action Plan. Gland, Cambridge: IUCN/SCC Equid Specialist Group. P. 113-117.

Bahloul K., Pereladova O.B., Soldatova N., Fiseako G., Sidorenko E., Sемmремre A.J. 2001. Social organization and dispersion of introduced kulans (Equus hemionus kulan) and Przewalski's horses (Equus przewalskii) in the Burkhara reserve, Uzbekistan. Journal of Arid Environments 47(2): 309-333. DOI: 10.1006/jare.2000.0714

Collins C.WW., Monfort S.L., Vick M.M., Wolfe B.A., Weiss R.B., Keefer C.L., Songsasen N. 2014. Oral and injectable synthetic progestagens effectively manipulate the estrous cycle in the Przewalski's horse (Equus ferus przewalskii). Animal Reproduction Science 148(1-2): 42-52. DOI: 10.1016/j.anireprosci.2014.03.018
Collins C.W., Songsasen N., Monfort S.L., Bush M., Wolfe B., James S.B. 2006. Seminal traits in the Przewalski's horse (Equus ferus przewalskii) following electroejaculation. Animal Reproduction Science 94(1): 46-49. DOI: 10.1016/j.anireprosci.2006.03.048

Crump Jr.J.P., Crump J.W. 1994. Manual semen collection from a Grevy's zebra stallion (Equus grevyi), onset of sperm production, semen characteristics, and cryopreservation of semen, with a comparison to the sperm production from a Grant's Zebra stallion (Equus burchelli boehmi). Theriogenology 41(5): 1011-1021. DOI: 10.1016/S0093-691X(05)80024-X

Durrant B.S. 1990. Semen characteristics of the Przewalski's stallion (Equus przewalskii). Theriogenology 33(1): 221. DOI: 10.1016/0093-691X(90)90645-A

Durrant B.S., Hoge M.L. 1988. Ultrasonography in a Przewalski's horse mare. Theriogenology 29(1): 240. DOI: 10.1016/0093-691X(88)90068-4

Kaczensky P., Ganbataar O., Altansukh N., Enkhsaikhan N., Stauffer C., Walzer C. 2011. The danger of having all your eggs in one basket - winter crash of the re-introduced Przewalski's horses in the Mongolian Gobi. PLoS ONE 6(12): e28057. DOI: 10.1371/journal.pone.0028057

Maksudov G.Yu, Shishova N.V., Katkov I.I. 2008. In the cycle of life: cryopreservation of post-mortem sperm as a valuable source in restoration of rare and endangered species. In: A.M. Columbus, L.V. Kuznetsov (Eds.): Endangered Species: New Research. NY: Nova Science Publishers. P. 189-240.

Maksudov G.Yu., Ivanov A.V., Malev A.V., Gilmutdinov R.I. 2014. Assisted reproductive technologies as an innovative trend of biodiversity conservation. In: Proceedings of the international scientific and practical conference «Biotechnology and quality of life». Moscow. P. 407408. [In Russian]

Monfort S.L., Arthur N.P., Wildt D.E. 1991. Monitoring ovarian function and pregnancy by evaluating excretion of urinary oestrogen conjugates in semi-freeranging Przewalski's horses (Equus przewalskii). Journal of Reproduction and Fertility 91(1): 155-164. DOI: $10.1530 /$ jrf.0.0910155

Pukazhenthi B.S., Johnson A., Guthrie H.D., Songsasen N., Padilla L.R., Wolfe B.A., Coutinho da Silva M., Alvarenga M.A., Wildt D.E. 2014. Improved sperm cryosurvival in diluents containing amides versus glycerol in the Przewalski's horse (Equus ferus przewalskii). Cryobiology 68(2): 205-214. DOI: 10.1016/j.cryobiol.2014.01.013

Stover J., Seager S.W.J., Dolensk E.P., Doherty J., Wildt D.E., Platz C.C. 1981. Electroejaculation and semen evaluation of the Przewalski horse (Equus przewalski). In: Proceedings of the Annual Meeting of the American Association of Zoo Veterinarians. Seattle. P. 144-145.

Summers P.M., Shephard A.M., Hodges J.K., Kydd J., Boyle M.S., Allen W.R. 1987. Successful transfer of the embryos of Przewalski's horses (Equus przewalskii) and Grant's zebra (E. burchelli) to domestic mares (E. caballus). Journal of Reproduction and Fertilily 80(1): 13-20. DOI: 10.1530/jrf.0.0800013 


\title{
РЕПРОДУКТИВНЫЕ ТЕХНОЛОГИИ И ИХ ПРИМЕНЕНИЕ ДЛЯ СОХРАНЕНИЯ ГЕНЕТИЧЕСКИХ РЕСУРСОВ РЕДКИХ ВИДОВ ЕQUIDАЕ: ОБЗОР
}

\author{
Г. Ю. Максудов ${ }^{*}$ К. И. Егорова \\ Научно-исследовательский институт пушного звероводства \\ и кролиководства имени В.А. Афанасьева, Россия \\ *e-mail: sapienceman@mail.ru
}

\begin{abstract}
В настоящем обзоре представлены данные об использования вспомогательных репродуктивных технологий для получения потомства и сохранения генетических ресурсов диких видов семейства лошадиные, включая лошадь Пржевальского Equus ferus przewalskii. Описаны полученные результаты и применявшиеся методики при получении и криоконсервации сперматозоидов, трансплантации эмбрионов, в том числе межвидовой, а также возможности изучения и регулирования эстральных циклов у редких и исчезающих видов эквидов. Основным видом получения спермы у диких видов эквидов является электроэякуляция иммобилизованых самцов. Приведены некоторые параметры сперматозоидов: $\mathrm{pH}$, осмотические характеристики семени. В немногочисленных работах рассмотрено влияние различных криопротекторов и разбавителей на выживание сперматозоидов при криоконсервации. Криоконсервации подвергались сперматозоиды лошади Пржевальского и зебры Греви E. grevyi. При искусственном осеменении замороженно-оттаянной спермой зебры забеременела кобыла домашней лошади $E$. $f$. $c a$ ballus. Изложены результаты трансплантации бластоцист лошади Пржевальского и зебры Гранта $E$. quagga boehmi домашним ослам E. africanus asinus и пони E.f. caballus, как хирургическим, так и нехирургическим методами. При хирургической трансплантации девяти эмбрионов лошади Пржевальского пони родилось четыре жеребенка. Двенадцать эмбрионов зебры пересадили пяти пони и семи ослам. У двух пони родились жеребята, от ослиц до родов не развился ни один эмбрион. Единственный опыт нехирургической трансплантации эмбриона зебры был неуспешен. Показаны результаты изучения эстрального цикла кобыл лошади Пржевальского и зебры Греви, как с помощью ультразвуковых исследований, так и по анализу образцов фекалий и мочи. Для ряда других диких видов эквидов циклику определяли по поведенческим реакциям. Опубликована возможность влияния на циклы кобыл лошади Пржевальского при оральном и инъекционном введении простагландинов. Результаты использования вспомогательных репродуктивных технологий на домашних лошадях рекомендуются использовать как возможную модель для создания генетических банков диких видов эквидов. Дальнейшая оптимизация высокотехнологичных методов, таких как интрацитоплазматическая инъекция сперматозоидов, клонирование, применяемых в репродукции домашних лошадей делают перспективным их применение для сохранения редких видов эквидов в будущем.
\end{abstract}

Ключевые слова: Equus ferus przewalskii, вспомогательные репродуктивные технологии, генетические банки, дикие виды лошадиных, криоконсервация, трансплантация эмбрионов 